\title{
The poetry, a christian resistance support in Romanian prisons
}

\section{Ana NECHITA*}

Abstract: Documents of special importance for their content, giving the voice of a tumultuous and broken destiny, which marked the young generation of the 1960's, the poems of communist prisons are a significant sound of experiences had in suffering by those who wrote them. Pages written with blood, these poems by their testimonial value, require from us not to ignore their long sacrificial experience, using the freedom, stolen to these authors, for the rebuilding of the nation and the reconstruction of historical truth. The prison poetry, being between the fighting weapons of spiritual resistance, is located near the divine, tending to transfiguration, thing which is happening not few times. Thus, poetry of the prisons becomes a direct way of communicating of the one behind the bars with God.

Endowed with the talent of rhyme and having the conscience of fight for truth, for a Romanian creed, these ,, angels of pain”, as they were called poets of communist prisons in Romania, assured their spiritual survival by sacrificing the best of them on the country altar, replacing the moments of indignation with life in spirit, and here pain is receiving a salvation sense. The lyrics of the imprisoned poets, springing out from pain and completed through pain, formed bright candles from the overflowing of their hearts for all those which was facing the same situation. In the shadow of the cell, under the lightless

* Professor of Romanian language and literature at "Ion Holban" Technical College, Iaşi. Romania 
vault of the lead mines, along with prayer, the poetry was a saving word, a flasher that lightened and assuaged in the darkness.

Keywords: prayer, poetry of the prison, communism, detention, angel, sacrifice, literature, memory, land, creed.

\section{Introduction}

There has always been a poetry of prisons, of the black hole, which was practised by the prisoners, the history of universal literature not being poor in these examples. However, there is some difference between the literature of prisons before the communist regime and that of Communists. The latter created a cage, in which the man should be destroyed completely and slowly, making the detainee not to miss the thought, thing impossible to achieve, but to miss the instruments of recording this thinking (paper and pencil). In spite of these inquisitorial measures, the post-grammar literature did not cease to exist, and moreover, it received a special feature by the thing it was written in mass proportions, despite the fact that printing was made in memory. The circulation of the literature from the barbed wire, in particular, of the poetry, was made orally, being transmitted from 'memory to memory'. Knowing the conditions of detention, from what was read or heard from those who have passed there, we will probably understand what poetry meant in prison, and it would not see too much to say that beside prayer it meant food for the soul, scale to heaven, strength and hope. Carnal poetry has the value of a testimony, of the pain, and of the approach in which detention conditions were reflected on the soul of the imprisoned; it has not only a literary value. In the condition when death was in front of the imprisoned, the past and memories were forbidden, the future was almost non-existent, and the present too much painful for a human being, the poetry became prayer even if it was forbidden.

Poetry was persecuted itself, so that why the mind and the memory were the only ones that could hide it. "Who can believe 
that for a cigarette-sized paper roll you have been mistreated and kept for days, naked in the black cell, without bed and without food? For the recitation of poems in prisons convictions were given between 10 and 25 years, for their dissemination there was forced life labour, and for their passage into the free world were invented plot for which sentences were sentenced to death"1.

Born in such conditions, poetry represented a strong resistance weapon during the communist period. She has gone beyond the level of thought and feeling, being a living, a drop of being and the fruit of suffering. "The rationale of being the poetry of the concentred universe lies not in the object, but in the act. The fact of writing it - improperly said, about the pen and paper cannot be said, as if to memorize it is relevant, not the poem as such. The act changes the soul. The poem can be confiscated, may be hoarded, can be burned; the act, once produced, no. In the shadow of the cell, under the shelter of the lead mines, along with libraries and skilful bodies, sometimes inanimate, along with prayer, poetry was such a word, not saved by speaking, as Lucian Blaga says, but a savior. More homage than this, to poetry, I think it is not possible. In communist dungeons in Romania, poetry was converted into bread and wine, sacrificial flesh and blood. And how good and beautiful it would be for this conversion to remain a good gain"'.

Starting from the two dimensions of prison poetry: a spiritual one, describing the poet's relationship with the divinity and a deeply human one, of suffering, Ioana Cistelecan puts into diction the interdependence of poetry-mysticism. Thus, poetry designates an inner call, first of all, being "accepted as a lyricism with a function of conserving the spirit / spirit by deepening a

${ }^{1}$ Zahu Pană, Radu Gyr, in "The Romanian Word” Magazine.

${ }^{2}$ Viorel Gheorghita, Poets after the Bars, Petru Vodă Monastery, 2010. 
relationship of the incarcerated with the divine" 3 . In other words, the incarcerated creator assures his spiritual survival by building and maintaining a personalized relationship with divinity ${ }^{4}$.

This communion of the incarcerated with God led to the transfiguration of sufferance, replacing the moments of rebellion with living in spirit, and pain receiving salvation. The poems of the imprisoned poets, bursting from the flames of sufferance, and completed in the pain anvil, constituted candles of enlightenment for all those who endured the same harshness. The walls began to speak a strange language in points and dashes in the Morse system. The cold pipes of the radiators became corridors of hot words, lyrics and their cadences became twin heartbeats ${ }^{5}$.

In most memorial works about communist prisons, it is being discussed the cheering and saving force of the poetry created by the imprisoned. There is not a word that could express how much solacing it was, in an infamous insulator to put your head on a metaphor of Radu Gyr, to cover you with a blanket of a verse by Nichifor Crainic, to take the hand of Ciurunga and to sigh being made free from loneliness, kissing near Vasile Voiculescu the feet of the "Angel of Pain"6. This relief of poetry, however, comes in completing the prayer because there is not a survivor of communist prisons who, being asked what helped him to withstand, do not answer: "Faith in God". Constantin Tăculescu states: "If I had not been faithful, I would not have succeeded. Those who did not believe stayed there forever. In the most difficult moments of a man's life, the only hope, the only straw who clings to, is faith in God. That's where I really

3 Ioana Cistelecan, Poetry Carceral, Bucharest: "Paralela 45" Publishing House, 2000, p. 12.

${ }^{4}$ Ibid., p. 15.

${ }^{5}$ Aspasia Oţel Petrescu, in Poetry after Bars, p. 11.

${ }^{6}$ Ibid., p. 12. 
discovered it. Faith in God is the most important factor. And what helped us a lot, were the poems of Radu Gyr"7.

What helped the survivors to resist was precisely the assumption of sufferance through which they became like the Christian, closer to God, considering, as Iov, indebted to win the "bet" between God and Satan. Thus, the first weapon of former political prisoners was prayer. In spite of the torture they were subjected to, their soul and conscience could not be chained, the heart being keeping and practicing genuflection before the only authority that deserves this. The state of the heart was impossible to see through the hole, and its kneeling before the divinity was well masked by the sufferance applied by the persecutors. There are countless testimonies of the holiness lived in communist prisons. Thus, Aiud's prison survivor Ilie Tudor ${ }^{8}$ confessed in a conference that the greatest care in prison was for the neighbour, so it was a continuous sacrifice. We have been saved by radiator and poetry. When the radiator was beaten, around perfect silence was coming and through Morse code were listened poems and preach. Father Dumitru Stăniloae was preaching every Sunday. The hardest thing in prison was to do nothing. However, it was an atmosphere of holiness, and that is why I once wrote "I miss Aiud". I miss Aiud, but not the hunger and the cold from there, but the state of holiness where we were forced to live and which saved us ${ }^{9}$. Also, it is known, also from the confessions, the emotional scenes of Easter celebration in prisons, in which prisoners, at the risk of being shot, sang the Resurrection Liturgy or moments of it. In this respect, Ilie Tudor states: "The blessing was given at 24:00 and we sang the entire Resurrection Liturgy

${ }^{7}$ Dumitru Andreica, Drumuri ... , p. 190, apud I. Cistelecan, p. 26.

${ }^{8}$ The father of the artist Tudor Gheorghe.

9 Conference "The Christian Confession in the Communist Dungeons", February 24, 2011, organized by the Faculty of Orthodox Theology "Dumitru Stăniloae" in Iași. 
from outside without realizing that I know it. We did not have candles, but we had light from souls. They all sang "Christ has risen!», not too loud, harmonious. (...) It was a joy that I have never met before. For me, it was the most beautiful service I have done over the years. It was a special experience, and the Pascale hymn was sung from the heart, from the soul" 10 .

Another weapon of incarceration was the beliefs for which they suffered and which they preserved even if they were having an unequally fighting against those who were just now showing their true face. Giving them hunger, making them chained, being mocked and humiliated many of them still have the strength to ultimately defeat their opponent, even if it meant to give their life. Those who have proclaimed themselves gods, masters of human matter, have never been able to understand the spirit, this thing leading to the loss of struggle by the final victory of the incarcerated. Being double-dyed they felt like they were taking it from the end, not understanding that with each whip, every swear or blow of a boot, they were approaching themselves to their own collapse. There are testimonies according to which, not a few times, the dying man was expressing in the moment of death: "I am happy to die for Christ!"11.

The weapon against communism for the incarcerated were memories too, because the connection with the exterior was broken. These memories, transformed into wandering shadows through the detainees' visions corner, imagining those who had once enlightened the life of the prisoner - mother, wife, children, friends, teachers - were a reason for resistance, a reason to continue the fight sot that it will not be in vain your sufferance and theirs. How much painful can be the abdication of the fight

${ }^{10}$ Ilie Tudor, a former detainee, 60-year-old church singer.

${ }^{11}$ Valeriu Gafencu, in "Veghea" [Calvary of Aiud], Year II, No. 4, Braşov, (f. e.), 2009, p. 53. 
for those who did it, in that moment, when they see their family and connections? Is there a greater punishment than that of own conscience?

Being between the fighting weapons of spiritual resistance, the carceral poetry is located near the divine, tending to transfiguration. Gifted with the talent of rhyme and having the conscience of the fight for truth, for a Romanian creed, they brought relief to those who were subjected to mind incarceration, more painful as were more people for whom intellectual work was in progress and had great significance. The kidnapping of the right to information, to study, or even memory was unimaginable. Their resistance, manifested by the use of original means of writing (on shelled soaps, on the sole of the boot, on thin sheets resulting from the bedding of some pieces of cardboard by ingenious processes etc.) or by memory exercises, were meant to leave to the descendants this valuable work called carceral poetry or detention poetry, or how we want to call her when we notice her existence, through an engaged reading we owe to her creators, and to those who risked their lives to convey further this "laurel of miracles of the world", as Lucian Blaga said.

The „Angels of Pain”, as they have been called prisoners poets, they have created both for them and for those who are beside them in suffering, but also for those who want to know the truth about their past, thus leaving the pattern of the subservient human being model, trusting and indifferent, whom "stalinism" created so, "solemny". Revealed within the bounds of this communist pattern, the ordinary man is hardly trying to find out his true identity. In his support, however are coming these personalities of the 1930's, which can not be ignored indefinitely.

But who are they? Nichifor Crainic, Radu Gyr, Andrei Ciurunga, Ionel Zeană, Bucur Stănescu, Virgil Maxim, Aurel Pastramagiu, Ion Maracineanu, Emanoil Paraschivas, Simion Giurgeca, Fronea Badulescu, Gabriel Tepelea, Stefan Vladoianu, 
Aurel Dragodan, Nicolae Nicolau, Eugen Magirescu, Petru C. Baciu, Demostene Andronescu, Ion Păunescu-Daia, Dumitru Radu-Udar, Tiberiu Hentea, Costin Dacus Florescu, Gheorghe Popescu-Valcea, Marin Cioaba, Simion Lefter, Petre Strihan, Ilie Imbrescu, Gheorghe Gorunescu Penciu, Gheorghe Ardeleanu, Petre Baicu, Vasile Blanaru - Cezar Flamura, Mihai Buracu, Cornelui Deneşan, Luca Dumitrescu, Ion Florescu, Viorel Gheorghita, Aurelian Guta, Grigore Lechintan, Virgil Mateias, Gheorghe Nastase, Ana-Maria Marin, Dumitru Oniga, Ion Paragina, Vasile Panzariu, Ioan Victor Pica, Gheorghe Stanescu, Virgil Vasiliu, Deliu Iulian Bălan, Mihai Dragodan, Valeriu Gafencu, Paul Galeşanu, Ion Golea, Sergiu Aurel Mandinescu, Vasile Militaru, Dragos Morarescu, Despa Olariu, Gheorghe Olteanu, Ion Omescu, Constantin Oprişan, Zahu Pana, Traian Popescu, Valerian Turtureanu, Nicolae Calinescu, Zorica Latcu, Corneliu Coposu, Teofil Lianu, Vasile Tacu, Stefan Tumurug, Eugenia Andreica-Damian, Dumitru Bacu, Petre Grigore Anastasis-Puiu Năstase and many others.

\section{Nichifor Crainic}

Nichifor Crainic was one of the leading personalities of literary and political life. Being a controversial figure, he justifies his deeds in the Memories, considering that his life and his writing, according to moral laws and the laws of the country, are a sacrifice on the altar of the motherland.

Born in the village of Bulbucata, Vlașca County, on December 22, 1889, Ion Dobre, after his real name, is the son of Nedelea and Dobra Stanca. He attends the primary school in his native village, then the Central Seminary in Bucharest (at admission in 1904, he has the maximum mark), then between 1912-1916 he was a student at the Faculty of Theology in Bucharest. 
Ion Dobre debuts with his signed poems in the magazine of the National High School in Iasi, titled "Towards the Light". Because of the rules imposed by the new director, Iuliu Scriban, he has to use pseudonyms: Victor Rațiu (1908), D. Crainic (1909), D. I. Nichifor, D. I. Crainic, Nichifor Crainic (1913) ${ }^{12}$. He publishes poems in the magazines "Ramuri: Branches" (Craiova), "Orthodox Shepherd" (Pitesti), "Junimea" (Râmnicu Vâlcea), "Romanian Culture" (Craiova), "Luceafărul" (Sibiu), ,"Romanian Life" (Iași), "The Sower", "The Romanian Nation", during high school studies. Between 1912-1916 he published in the magazines "Literature Light", "Orthodox Magazine", "New Light" (Bucharest), "Cosânzeana" (Orăștie), "Political and Literary Magazine" (Blaj) "Branches" (Craiova), "Romanian Life" (Iași). The debut in volume is produced in 1916 with Native weald in Craiova. The volume is welcomed by Nicolae Iorga, who recognizes in Nichifor Crainic the "true poet of our generation" 13 . His word fell hard and was considered sanctification" ${ }^{14}$. "Also in 1916 Nichifor Crainic publishes the volume of poems "Smiles and Tears" at the Alcalay Publishing House in Bucharest. Fugitive in Moldova, during the German occupation, collaborates with the magazine "The Romanian Nation" in Iași. Returning to Bucharest he becomes editor of the "Dacia" Magazine, at the magazine "Morning Star", in which he publishes a sketch of what would later become "Thinking"15.

In 1919 appears a volume of essays titled "The Icons of the Time" appeared at the Steinberg Publishing House, Bucharest, and a year later, the volume of poems "The Gifts of the Earth" at

${ }^{12}$ Ioana Cistelecan, op. cit., p. 33.

${ }^{13}$ Eugen Lovinescu, Critical, No. 2, Bucharest: Minerva Publishing House, 1982, p. 261.

14 Nichifor Crainic, White Days, Black Days, Memories [care by Nedic Lemnaru], Bucharest: Roza Vânturilor Publishing House, p. 199.

${ }^{15}$ Ibid., p. 138. 
"The Romanian Book" Publishing House, Bucharest. In the same year, at the recommendation of Lucian Blaga, he went to Vienna where he studied theology and philosophy, becoming a member of the Literary Academy "România Jună" of romanian students in Vienna. In 1921, the Romanian literary magazine "Thinking" appears at the initiative of two young people, Cezar Petrescu and Gib I. Mihăescu. They proposed themselves first to react against the effects of various avant-garde movements of the twentieth century that fought the Romanian literary and cultural tradition. With the return to tradition, which could only be autochthonous, according to the founders, the magazine boosted the development of a literature that started from a strong moral impulse. The awakening of the religious sense of life, of philosophy and of the art as a reaction against positivism and naturalism that dominated the era was one of the preoccupations of the young people who published in this magazine. After 1926, the year in which Nichifor Crainic takes the leadership of the magazine, it can be spoken about a movement inspired by the magazine, a movement called "thinking" or "orthodoxy". "Thinking" is defined as aesthetics and ethics, a religious and also political orientation. It uses the force of Orthodoxy as a traditional religiosity, indicating a transformation of the world and of life through spiritualization. The role of this magazine, very important, was to launch and encourage the best contemporary poets, including Lucian Blaga, Vasile Voiculescu, Dan Botta, Ion Pillat, and created a critical stream that they took into account, in general, literary historians, from Tudor Vianu to Ovidiu Papadima and Vasile Băncilă ${ }^{16}$. "Gândirism" (Thinking) is the magazine through which poetry has manifested many of its availability to the new ${ }^{17}$. Nevertheless, "gândirism -thinking" does not have to join

${ }^{16}$ Ibid., p. 98.

${ }^{17}$ Mircea Diaconu, Poetry from “Thought”, p. 42. 
absolutely the doctrine of Nechifor Crainic from a certain stage of the magazine, and the dissociation between ideological and political thinking is absolutely necessary.

In 1926, Nichifor Crainic became a professor at the Faculty of Orthodox Theology in Chisinau, taking the course "Modern Religious Literature" and "Mystical Theology". The following year (1927) was delegated to the Writers' Congress in Brussels, and in 1930 he received the "National Poetry Prize". The next year (1931) appeared the volume of poems "Country of the Old Age" at the Romanian Publishing House, Bucharest. The theorist of Corneliu Zelea Codreanu's legionary movement, Nichifor Crainic is setting up in Bucharest the newspaper "Calendar", in which he publishes ideological articles (such as the one concerning King Carol II and Elena Lupescu, which will lead to his temporary arrest). Although the relations between Nichifor Crainic and the legionary movement (Corneliu Zelea Codreanu) had cooled down, and I. G. Duca is assassinated, after dissolving the Iron Guard, Crainic is arrested, being considered the moral responsible of this crime. Disappointed with the legionary movement, Nichifor Crainic enters the party of A. C. Cuza, realizing a merger between this party, whose vice president is becoming, and the party of Octavian Goga, whom he considered to be a weak man in politics. After the formation of the National Christian Party on July 4, 1935, Nichifor Crainic is again disappointed and withdraws from politics. Turning to the essay activity, in 1936 he published the volume Cardinal Points in Chaos, then Orthodoxy and Ethnology in Bucharest at "Cugetarea" Publishing House, trying to establish the new spirituality of the Romanian elites on Byzantine Orthodoxy and on the national tradition.

Although in 1939, at the age of 50, he intends to abandon journalism, dedicating himself to the chair and literary life, he cannot be far from political life, accepting various functions 
(Minister of Propaganda in the Government of Gigurtu, President of the Broadcasting Corporation in the Government of Ion Antonescu, Minister of National Propaganda in the same government, president of the "Romanian Film" Cooperative, president of the Romanian-German Association in 1944). The events of August 23, 1944, find Nichifor Crainic out of the events. However, he lives the drama of a wanderer in his own country, being called a "war criminal" and "traitor" of the new regime and sentenced in his absence to life imprisonment in the "journalist group", together with Romulus Dianu - 20 years, Radu Gyr - 12 years, Grigore Manolescu, former minister sentenced to death, Stelian Popescu - sentenced to death, Pan Vizirescu - life imprisonment. Confident in the future of the country, Nichifor Crainic refuses to cross the border and leave the country, assuming his literary and political activities until then: "In my country I am not afraid of my deeds" $" 18$. Being not able to stay in Sibiu because of the Romanian-Soviet raids, Nichifor Crainic moves to Transylvania, where he has been traveling for two and a half years, through five counties, having another identity (Ion Vladimir Spânu, a citizen of Gălănești commune, Rădăuţi County). Nichifor Crainic begins to write the essay "Spirituality of Romanian Poetry". Even though the situation in the country can be defined by a whole series of unknowns, Nichifor Crainic, perhaps encouraged by the opinion of people with whom he had discussions, intellectuals who believe him an unknown and defend him, hopes to be renegade and rehabilitated when will surrender. Thus, after experiencing a tense period of false identity, sheltering at his former students, generally priests, with an appreciable moral stature, he decides to surrender. To his decision may contribute the news of his brother's death found out from the telephone operator from his native village, the news

${ }^{18}$ Nichifor Crainic, Memories, p. 31. 
about his wife's death in 1946. She "died of misery and was buried with the tale"19. Crying his wife in front of an unknown tomb, Nichifor Crainic appeals, as he will do later on, to the comforting force of poetry turned into prayer, which he loved beyond the tomb $\mathrm{b}^{20}$. Not having much to lose, aware of the fact that his daughter can do everything by her own, as he cannot help her, decides to surrender. Being at Cerghid, near Târnăveni, at the priest Ioan Sămărghițan, a former student of him, N. Crainic sets a surrender plan according to which no one, besides him, should suffer. Thus, the priest is convinced to surrender him to authorities in order so that he will not raise suspicions about him $^{21}$. At the Văcărești Penitentiary, under a special instruction, a retrial of the 1945 process is attempted, but this is abruptly interrupted, the detainee being sent to Aiud, where he remains 15 years until March 1962.

About the illnesses, the beatings and especially the "hallucinating hunger" suffered in prison, which we can imagine after talking about the phenomenon of Pitesti, he speaks to us in the same paper: "Memories"22, considering this an assassination attempt: "This unusual investigation was a formal confirmation to me that I was living under a special instruction for 12 years, which meant a slow attempt to assassinate me. The atrocious sufferings I had endured so far, with the superhuman powers of my body, confirmed the persistence of the special condemnation I had known since the beginning of martyrdom"23.

Transferred to Bucharest in 1962, at the request of Ion Drăghici, N. Crainic writes a history of the Legionary Movement

${ }^{19}$ Ibid., p. 107.

${ }^{20}$ It's about Psalter.

21 "Pr. Ioan Samarghitan had four children and I did not want to suffer any punishment”, N. Crainic, op. cit., p. 151.

${ }^{22}$ Testimonies from prison.

${ }^{23}$ N. Crainic, op. cit., p. 157. 
titled "The Nest of Killers", as well as a letter by which he relinquishes his past, then receiving freedom under supervision and of course conditionally. This letter, published in "The Voice of the Motherland", was in fact the tragedy of Nichifor Crainic, which probably crushed him more than any jail: "I reopened my eyes in the light of freedom on a completely new country, in total opposition to the image of ancient Romania, which I had in mind" 24 .

Hope was for Nichifor Crainic one of the weapons that helped to withstand. Perhaps this thing stake on his ex-wife who, on her deathbed, encourages her daughter telling her not to worry about her father, because he will resist. He resisted up to the knowledge of despair, knowing the shadows of the primitive grottoes of the human soul, then descended to the limits of the human being meeting the animal from himself, especially of the others (torturers), he tried the sufferings of hell as he confessed to the release "I know hell" 25 . Then, signing or not the agreement with Satan (not important thing) to come back among human beings hoping again ... (much more reserved hopes after the hell of communist prisons) as we can deduct from Alexandru Draghici's words, said at the liberation of N. Crainic: "From this moment, Mr. Nichifor Crainic, you are a free man like anybody else and you have the right to write and publish as any Romanian writer today". It is true that it was about the freedom that a Romanian could have at those times and about the writings that could be published in the new conditions in Romania, or this freedom and these conditions were unimaginable for a man who still had the illusion of a return of things in their normal breast. The promised conditions of rehabilitation were not impossible for a writer of the national pathos with the bloody temper of Nichifor

${ }^{24}$ N. Crainic, op. cit., p. 14.

${ }^{25}$ Preface by Alexandru Cojan, p. 8 . 
Crainic, an ardent lover of country and peoples, a peasant son grown in the legendary spirit of the outlaws, always revolted against the corruption of politics, dreamer of christian egalitarianism, always ready to be illusive, with utopian projects of improving the lives of its peers ${ }^{26}$.

Editor of "The Voice of the Motherland" magazine between 1962-1968, Nichifor Crainic is experiencing a new hope when he writes and self-censors his memoirs and some poems for being published. Becoming then collaborator at "The Voice of the Motherland" and "Tribune of Romania" magazines, Nichifor Crainic assumes the suffering given by the troubled history of a people at whose foundation he put his talent and work, the way he knew. Thus, after ten years of conditional freedom, Nichifor Crainic fell like a broken storm oak, in one night in August at Mogosoaia, with a single consolation, which he confessed as a confession on the eve of the end I was born in a modest cottage as a son of earthbearers. Now I am in this palace of Brâncoveanu after I have given my talent and my work to the raise of this nation ${ }^{27}$. Indeed, Nichifor Crainic assumed the facts as he said at the beginning of his wandering: "In my country I am not afraid of my deeds" and I do not think anyone would have the right to judge it.

\section{The poetry of Nichifor Crainic}

Modernist and traditionalist at the same time, Nichifor Crainic is appreciated by Tudor Vianu as a "writer who does not take the pen in his hand than to impose a point of view or to

${ }^{26}$ N. Crainic, Memories, [Foreword], by Alexandru Condeescu, p. 12.

${ }^{27}$ Idem, Memories II, [The Calvary of Manuscripts], Bucharest: The Romanian Literature Museum "Orfeu", Dacia Publishing House, "Manuscriptum", f. a. [Careful edition and a word before Alexandru Condeescu]. 
knock down an opponent" ${ }^{28}$. Considered to be a sower, by E. Lovinescu, but not by folkloric influence, nor by rhythm, harmony or image, but by sensitivity: "His sowerism has exalted himself to an integral conception, which gives him an inner unity: solidarity, in space, with the earth and, over time, with the breed; on the one hand, therefore, a realistic and current inspiration; and on the other, the consciousness of a fragmented existence of a totally disseminated whole age" ${ }^{29}$.The poet of the sun in all his hypotheses, in our literature, Nichifor Crainic is compared with George Cosbuc, which, Ovidiu Papadima says, "surpasses him through his explosive vitality" 30 . It is true that Nichifor Crainic is the singer of the water, the valley and the plain, as well as the field, all of which are viewed in all aspects of the seasons, yet his poetry is limited to his native horizons. Nichifor Crainic comes in harmony with the rest of traditional literature without having an original vision. A poet of solidarity with nature without being exalted by the outer lines of his landscape or variations of sentiment to lend his personality, Nichifor Crainic remains a poet of an ideology: that the earth is the model of the human soul.

We can say, therefore, that the influence of Cosbuc is only in terms of form and not content. Starting from the dependence of "natal plains": "You, endless plains in the broad summer skies, / Quiet as them and luminous like them, / They flourish here and here they shake / In the mood of the weather, the maw of my childhood", to the line of ancestors who live in us through the instincts that they have determined and their ideology mingled in deliberations of consciousness, the passage became natural to

28 Tudor Vianu, Romanian prose writer, Chișinău: Hyperion Publishing House, 1991.

${ }^{29}$ Eugen Lovinescu, "Critical”, 2, Bucharest: Minerva Publishing House, 1982, p. 262.

30 Nichifor Crainic, Selected poems 1914-1944, [in the selection of the author], p. 10. 
Nichifor Crainic. As a consequence of a succession of generations in the patterns of a particular landscape, each of us concludes the cycle of servitude through nature and ancestors as it appears in the poem "Song of the Earth" in the volume "Songs of the Fatherland": "Fruitful earth, holy earth, / You who are my cradle, home, and tomb, / Raise to the fire of the same star / your beliefs, my beliefs" 31 . Becoming a poetry of cosmic solidarity and especially of traditionalism, free will and mobility are no longer noticeable in the text.

Nichifor Crainic's poem appears to be accomplished through an intellectual process, logic occupying an essential place in the development of poetical ideas. Lyrical spontaneity is easily shrouded by the lucidity of poetic exposure. The similarity of attitude between Nichifor Crainic and Alexandru Vlahuta was signaled by the literary critique in the direction of the sowerismus that evolved in traditionalism ${ }^{32}$. Thus, referring to poetry $A$ song during dryness from the volume "Native plains" E. Lovinescu recognizes "Cosbuc's background", "treated with intelligence and lucidity, according to the anti-poetic models of Vlahuta", poetry that highlights the themes of the tangible earth, and the one of the homeland: "The West had gathered out of the winds of the summer / And when the twilight sky lit up in the wilderness, I Far from the unclean smoke of the evening / A song of pain was mourning on the valleys / it was crying in himself the orchard and the sick land / And the boar that slept on the thresholds of the border / And susurration were trembling of sear after - grass / And the despair of labouring work in vain". The bucolic arrangements as well as the perfection of form are highlighted, achieving the balance between form and substance. Considered a classical poem (Lovinescu), "Song during dryness", is

${ }^{31}$ Ibid., p. 25.

${ }^{32}$ Eugen Lovinescu, op. cit., p. 263. 
nevertheless crossed by a didactic mysticism. Starting from a traditionalist sensibility given by his belonging to the soul of this nation, endowed with virtues cut on the dimensions of customs and traditions crystallized in the villages of the Danube Plain, Nichifor Crainic specifies his poetic program: "From the flight that hammer hurries / We learned the fiery impulses / And the rhythm, which brings forth harmony, / From the reeling of the grains in the winds. I You write now with the plow, the spring, I The land reach poetry; / I, heavy but sweet, I received my burden / To paint its divine magnificence" (The Poet).

A child from the village, the poet in question has integrated the style of peasant life dominated by Orthodox faith, but also influenced by myths and heresies. A great influence had on Nichifor Crainic the Big Friday the way it is passed in the Romanian villages with fasting and prayer, the people redeeming the burial of the Savior. As a predominant theme in Nichifor Crainic's work, the person of Jesus, who appears as a beloved local person, is the proof of a profound popular religiosity that will be transferred to the young man who left the village to discover Him and in elevated forms at the Theological Seminary Central in Bucharest or in Theology studies conducted in Bucharest and Vienna.

This fund of religiosity brought from the village led to the outlines of the great life truths that he began to dress in the golden word of the lyrics. With such poetry, admits E. Lovinescu, the literature of a people is lightening in honest and definitive specimens $^{33}$.

The poetry on nature topic as well as that of man's communion with nature is part of self-styled religious poetry ${ }^{34}$. It is understandable that poetry on the nature subject occupies the

${ }^{33}$ Ibid., p. 265.

${ }^{34}$ Ioana Cistelecan, op. cit., p. 45. 
first place between the lyrical preoccupations of Nichifor Crainic and, in general, of the thinking poets, this being a way of expression that seems more accessible and easier to express. That is why one of the signs of traditionalism is considered the pastel in which is recognized the return to the picturesque and native. These pastels may be the contextualized expression of a religious idea as well as the echo of the feelings or the voice of the memory. Thus, visualization is replaced by revelation (Ioana Em. Petrescu), as "the outer world is an inner world built upon the condition of the mystery" 35 .

The rural universe is the occasion of an attempt to reconstitute an inner world, space of childhood, ancestors or aesthetic space. In the "Fountains of the Past": "I see: from the silenced shadow/ I want to gather the new face, / But from my helmet mirror / an ancestor is laughing faded", Nichifor Crainic valuates the idea of the New Man in the light of ancestral religion. Aspiration to infinity is found in the Country upon the Ages: "To the land of Lerui-Ler / There is no flight, no iron road, / Only the pick of thinking, Only the soul trembling / And an boatman angel", and the seeker of divinity "In Song of Mountain": "With the fir the high sky is absorbing me / And when with cave when the wind beats, / I sleep with silence in loneliness / And with echoes on the moors I am perishing.. [...] / Fern that you get rid of without alleviation". "I want on the rocks to remain with the moss/, But with the springs I gather and handle / With them to the sea, to the sea". Bright images through which the poet goes out of the concrete and abstract to material, we notice in the poetry of Jesus in wheat: "Through the baked wheat (...) / I thought you were going, Jesus, as you passed that time / Tasting by walking the friendship / of fishermen of

35 Andrei Pleşu, Picturesque and Melancholy. An Analysis of Sentiment in European Culture, Bucharest: Humanitas Publishing House, 1972, p. 50. 
Galilee". "You were going ... and was bleeding in You / The persecution of the cruel soldiers / In horizons, you were expected by the cedars with giants, protecting branches, / (...) / Ages passed and with them / It seemed to me You passed again/ I'm looking for Your bright furrow / In the soft clay to kiss it".

In the poem "Memorial" we observe an abundance of visual fitting thus the pastel, but also a correlation between the tellurian and the celestial, creating the mystical mark: "Sit a little on the summits to look upwards / the chimneys smoking after the sunset; / The smoke of our house on the other side / It's taller and makes the evening even higher;/ It is more straightforward and blue and clear / It seems like incensing the stars in fervour". Transformed into religious hymns, the pastels of Nichifor Crainic are bathed in a metamorphosed light that gives the world the original status of consubstantiality with the divine: "will cover spummy, on the topping of abyss / by all over vibration of light / And I melted into the divine music boar / Discharged by the slag of evil opinions" (Infinity).

Nichifor Crainic has, as we can easily see, "the nostalgia of paradise". Besides, the historical context of the interwar period had the reverse the return to the Orthodox phenomenon, to the soul phenomenon, trying to create a new man, who would follow the moral rules of Orthodoxy. Assumed and transformed into norm, this dimension has somehow lost its authenticity. Likewise, the concept of religious poetry, not precisely defined, includes a broad thematic register, the respected canons being not necessarily those of Orthodoxy, extending also to mythology. In Nichifor Crainic's view, Romanian poetry is religious because it means "the melodious reaction of the subject to the surrounding world" seeking the meaning of the reality of the world "beyond the seen cosmos, in the eternal spirit"36. "The soul's health and

${ }^{36}$ Our Religious Poetry, Year XXII, No. 8, Oct. 1943, pp. 425-432. 
the signs of youth are revealed in the affective connection with the homeland's land, in relation to the ancestors and in connection with God", the lyrical "I'm not existing", as happened to the "poets of the great western city", "isolated and suspended"37. And if "Christian doctrine is the same" and "Christianity is universal", the ethnic temper of every people is making it autochthonous.

Some peoples with apostolic temperament convert others, others with mystical temperament are contemplative, some with a critical spirit looking for it philosophically, while others with artistic sense "receive it in the brilliant wonders of beauty. We, the Romanians, are a people that have lived in the generosity of heroism and mercy" 38 . In "Our religious poetry", Nichifor Crainic states: "The poets are God's disciples and admirers, perhaps related to Him more than any creature by its ability to transpose beyond the world, to see it from a divine perspective as the work of the eternal Father and by imitating Him in the shaping of beauty and harmony" ${ }^{39}$. He further states that the personality of the Savior, with the overwhelming mystery of the God-made men, which he closes in it, remains the inexhaustible source of artistic inspiration and the inaccessible peak, above any image they have tried to sensitize us $^{40}$. That explains perhaps the gravity of the Christological theme in Nichifor Crainic's lyrics.

On the other hand, by the way he composed his poetry anthology in 1929, Nichifor Crainic outlined his fundamental lines of poetry. Thus, God is equally in the fruitfulness of the Mother Nature ("Prinos": Offering) as in the soul of the peasant who divides the harvest of the earth, firstly to the travellers,

\footnotetext{
${ }^{37}$ Ibid., pp. 425-432.

38 "Transfiguration of Romanianism", XXII, No. 4, April, 1943, p. 177.

${ }^{39}$ Art. cit., Year XXII, No. 8, October, 1943, p. 425.

${ }^{40}$ Ibid..
} 
according to the pre-Christian ancient rites (or ancient testament) on Sunday morning, in the fruitful vibration of natal landscapes , in art and love as in falls and death. The image of death is humanized until it intertwines with life: "I have lived". Poetry The land over the ages, imagining eternity, presents an image of the passage in the beyond world, passing bedight in mystery but at the same time spent naturally, without much effort, "like a glimpse of thought", the ancestral soul (and by the word "ler"life more longer than that of Christianity), he lived his "ler" = lived his life, occupies his place in the Universe: I dream a corner of heaven beside the Creator who is none other than "Lerui-ler". Nichifor Crainic observes that at the basis of religious poetry there is a "peasant Christianity" that is somehow different from the dogmatic one; the peasant image is more free and more concessive than the discipline of dogmas. There is producing thus an interpenetration of sacred history with myth and legend "for extension into fairy tales like the waters of a river in the Sea"41. Nichifor Crainic accepts that "the legends contain a sensibility that humanises and Christianises the whole creature, plants and animals, which we see actively participating in the sacred history of the Savior and the Mother of God" "42. What interests Nichifor Crainic it is not that much the evocation of evangelical time, but a soul movement of godliness and faith. That is why living in another time other than apostolic is not the sign of a loss, but of fulfilment. He emphasizes the serenity of Christian sensibility through the contemplation of biblical characters and biblical events and their transfiguration into the everyday life of the Christian poet. Sacred time is now present and the poet can manifest its believing identifying it: "Through the baked wheat,

${ }^{41}$ Our Religious Poetry, op. cit., p. 432.

${ }^{42}$ Vasile Voiculescu, Poet of the Spirit, Year XXII, No. 7, August-September, 1943, pp. 361-370. 
where is running / my winding path / escaping far in gold / of glorious candlelight. // It seemed to me that you passed Jesus, / as you was passing that time / Tasting in walking the friendship / fishermen from Galileea.// on your hair, crowning it, / play a blond flame / And the sun dip garment / trekking in blaze // (...) // passed centuries, and with them / that you pass again I felt / I'm looking for your light / to kiss her in the soft clay" (Jesus through wheat).

Talking about the poetry of Nichifor Crainic, Lucian Blaga notes that there are expressions of a religious sensitivity "various typological variants", two are distinguished: one is poetry that emphasizes more on earth and the other pole of poetry emphasizing divine and heavenly. One is the "marcuin" style (originated in Mark's Gospel), the other "ionic". Crainic, consider Blaga would perform in his poetry, from one another, the "event saw" and "the temporary concrete" to "ethereal logos populated by sublime meanings" (It is envisaged the development from Natal plains to The country after ages $)^{43}$. For Nichifor Crainic, the time when he is living is one that eschews the encounter with the divinity, and the world is built around the "I self", because of the faith: "Stand on your way a house, and the way is my age ages. / You are judged, o, Lord, to wander always / And my threshold, the humble, you can touch / That my heart prays to me, but the mind rejects you" (Traveler). Thus, the soul of the poet is marked by the solemnity of life and its divine meanings. Thus, the religious poetry of Nichifor Crainic is both poetry of biblical motifs and ethnographic locations, and one of the religious mystery and to each of these forms is associated an implication of the self.

${ }^{43}$ Vasile Voiculescu, Poet of the Spirit, Year XX, No. 6, June, 1941, pp. 278288. 
Nichifor Crainic's carceral poetry is found in the volume of "Falcon on the Chasm", verses created in Aiud's prisons where "poet's prisoners" with forbidden or self-mortified senses have created a poem that resembles to a normal poem, although the conditions of poetry creation was totally abnormal. Like Homer, they did not have a paper clip or a pencil. They created in spirit, they remembered and were repeating in memory. That's how I composed in the head the volume of "Falcon on the Chasm", so specially titled to indicate the presence of the free and sovereign spirit that can dominate the tragic constraints of life "44.

Being himself a falcon over the Communist chasm, with interior flights subject to suppression, Nichifor Crainic overcomes his disappointments by saving himself from the mantle of the spirit. This thing happened through confrontation with reality and implicitly with the truths experienced. Thus we find in the volume in question a tragic poem of the creature subjected to an inhuman regime, abrogating himself, the senses and the body exhausted by carnal suffering, is not being useful at all: "I have nothing to do with my dry hands", "I have nothing to do with my poor feet", "I have nothing to do with my eyes, with no faces", and "happiness to work" being forbidden: "Blessed are the miners who sweet/ At the bottom of prison and all those who hold in the hand, steaming, a dig, a hammer or a pen" (A sick song). Rejecting his identity as a human being by reducing himself to the most primitive state of imagination, Crainic writes on the immaterial memory the flying verse containing "the soul received from the ancestors" 45 .

"To my glorious origins / I descend deeply from myself to myself, / (...) / With my romantically cut hair/ Under my Dacian hat // In the sweet poetry of the mother Dochia / Slipping from the

${ }^{44}$ Nichifor Crainic, Memories, pp.183-184.

${ }^{45}$ Ibid., p. 187. 
parents to the infants, / And opening the eyes in this world / In the present I am that of those times" (I).

Reaffirming his identity in time and homogeneity in the ancestral space of the Romanian nation, N. Crainic is excited to rediscover himself in "those who have not been" and in "those who come": "Instead of leaping in myself millions / With the future they are in / in the race for the eternal rush / as I am what I was and will be what I am". The synthesis of his belonging to the Romanian people is given by the verse "I take the crop field in a bread the Country in a Doina" from the poetry "Ancestral Song".

Nichifor Crainic's lyrics express the weakness of the human being, its smallness's and doubts in front of difficulties. Composed "in state of half-sleeping given by the permanent ascetic of hunger" 46 the stings are full of bitterness, of grievous suffering, and clinging with eternity to the dark and cold reality of the cell, the poet cries out his helplessness and hunger: "If I would be sometime a bob / I am a squeezed bean today in winepress / In the hunger from myself / Pour a soup and I will rebirth / (...) / In the land of the flocks and of the bread / I lay down on a spoon and dish, / Leave me alone with the dogs to eat / Or I will beg around the wall" (Song of hunger). The wandering of the steps "in a hungry wilderness" does not prevent him from bowing his knees before the Lord and asking mercy: "If I become hungry, / the thought is pushing me only to food, / Goodness, I ask for forgiveness, I I am a heap of dust" (Hunger). Similarly, in poetry "The Song of Hunger", the poet asks for the repetition of the miracle of bread multiplication in favor of the "thousands of mouth" and not of the poet. It is remarkable the magnitude of asceticism made through charity with the thought the poet does, the only one available to him in the prison conditions. The one

${ }^{46}$ Ibid., p. 186. 
who demanded the right to even dream of a chicken soup, a soup of amaranth, an apple, a puddle sauce, or a mushroom soup is content with that basket of crumbs that could signify the strengthening in the faith or the power to resist at the end of the crumbs of hope that would have gathered from those fed with the reward of their suffering for faith.

The first form of manifestation of the spirit, in history, was the prayer imposed by powers above man, and immediately after that followed the poetry "required by the moments of the spirit" was followed. This is also the order in which N. Crainic puts in value his creative spirit by creating poetry-prayer. Lived in the light of faith, but also in the darkness of hopelessness: "My insufficient belief / Mutter without sight, / You are searched in silence /Like in an impenetrable pitch / (...) / Where are you as I do not see you / Who are you as you keep quite all the time? / My torment forever / Live I feel you, but I do not know where" the poet's belief is an apostolic one.

The poet is convinced that people continue to exist through their souls, and as the conditions of detention destroy the body, he can only hope for a rescue of his soul, both of himself and of those near him or of those who have gone into the beyond world. Seeing death, as a passing into a perfect world and feeling its "twilight", almost the poet urges us to pray for those who have passed away, being they "partisans" or "enemies" transforming the human feelings that might exist in the soul of a suffering in divine forgiveness, which is meant to open the gates of love: "I pray for my living and for my dead one / And now one are my adepts and my enemies / With them in the same manner I have also broken my years, / And love and enchantment, I have shared with them. //.../ And by gathering my alieves, at your mercy I recall, / When the white crust of the day the earth crowns: / You, God, give it with all your good hand / The late wisdom from my sad twilight". Detained from 
the pain of those beside him, the poet asks God to give them a mature, wise way of understanding things so that, in prayer, they do not lose what is most important in 1 and beyond the world, namely the eternity of the soul. Asking "Where are they who are not anymore?", the poet consider that the answer is not known to us, being an impenetrable mystery, to which, however, he attributes a superior state to those known by people. Thus, the wind asked about "those who are no longer" responds that "Their unseen wings break me in flight"; the flying lark in the high light responds that "they are hiding in the light of the impenetrable One", the owl which see in darkness deepens the mystery finally, saying, "When the great dark will fall, you will see", the great-dark being actually the supreme light (the owl being blind all the day, considers the light dark, and the light that surpasses our power to see becomes dark). Thus, the poetry of Nichifor Crainic is largely a poetry of mystery, this poetry being born in prison, where the spirit uncovered by asceticism has found its divine origin. Perfect and reconciled with God, the poet shares the presence of Christ in the Song of the Grail: "And behold, the chalice upon your mouth brings you, Jesus Christ, you sacrifice on the cross; / Adapt me, the sacred holy God / As the bean in the spice and the gravy juice in clusters / You are everything in everything, and all through You, / You, the everlasting wine of my people". Long and burdensome with many passions, stumbling of helplessness, despair and crucifixion, the poem of sufferance has culminated, however, with the resurrection hoped for by the poet: "Late, when the night came down, / There came a shadow as icons, / On the hands with signs of nails / And a heart that blew. On the face burned with torment and woe / Ofting kisses him hot / With eternity in words: / You will be with me in heaven today" (Milogul). 


\section{Radu Gyr}

The poetry of Radu Gyr has relieved the suffering of the detainees being spiritual food like prayer. For 20 years, Radu Gyr has "chased" several camps and prisons (Râmnicu Sărat, Vaslui, Miercurea Ciuc, Jilava, Aiud, etc.) paying political or imaginative guilt. Thus, in 1938, when King Charles II established his dictatorship, he sent him to the camp because he was part of the radical right-wing intellectuality by belonging to the Legionary movement. In 1940, when the legionnaires came to power, he was freed and became general director of the theatres and Operas of Romania, period during which he founded the Jewish theater "Baraşeum" - the only one in the world at that time. After the legionary rebellion, Antonescu involved him, being judged with 86 other intellectuals and sentenced to 12 years. After the start of the war in the East, detention was interrupted by sending it to the front line. After two years of harsh war he is seriously injured in Vinogradov, returning home. He writes the volume of "Poems of War" (1942) that Soviets dislikes. On August 23, 1944, being in convalescence, he is arrested in the batch of journalists and writers (the second wave, the first being of the generals Macici, Trestioreanu, etc.). He is sentenced to 12 years of hard work. In Prison in Brasov and Aiud, he writes poems and sends them home (with the "censored" stamp on them) after that date then, contact with the family is forbidden, the cells are emptied of any pencil and paper and the prison becomes place of extermination. Under these conditions, the poet "writes" his poems only in his memory (of himself or of others). At the end of 1955, shortly before the expiration of the 12 years, he was released, but in 1958 he was arrested again because of the so-called anti-communist manifestation, which is the poem "Raise yourself, Gheorghe, raise up Jones". The punishment is the death sentence, which he expects for a year, in chains, after which he is informed that he 
has been forced to work for life. In 1963, he was pardoned, but he lived until 1975 in detention in freedom heavier than in jail. Referring to the literary life of Radu Gyr, we recall that he debuted in the newspaper "Rampa" in 1922 signing Radu Demetrescu, after his real name. There have been collaborations in magazines like "Literary and Artistic truth", "Branches", "Literary Universe", "Foundation Review", "Literary Conversations", "Family", etc. In 1924, the volume of lyrics "Quiet hermitages" appeared in the "Romanian Writing" in Craiova, then in 1927 "Crooked wood cries", in 1928, "The Deer of Light", in 1936, "The Stars without a Swing", in 1938, "Dried Crowns", in 1939, "The Ship with the Bush". in 1942, "Poems of war", in 1943, "Ballades".

His works include pieces of theatre in literary texts, studies and essays, in which he debates problems of the writers and books fate: "Ballad and Romanian Soul" (1938), dramatic literary reviews, dramatical cronics, poems and stories in lyrics for children (Mutu Cotoshman, Bimbirica in the Moon, Baba cloantsa cotoroantsa, Why the bear do not has tail) translation in Verlaine, Baudelaire, Goethe, James, popular German ballades, sign medallions and literary portraits about Elena Farago, Claudia Milian, Otilia Cazimir, Emil Gârleanu, Gib I. Mihăescu, etc. He is distinguished by numerous awards: [the Romanian Writers Society's Sonnet Award (1926), the Poetry Prize of the Institute of Literature (1927), the "Adamachi" Prize of the Romanian Academy (1930), the Prize poetry "Socec" of the Society of Romanian Writers (1939), etc. The society in which Radu Gyr is formed in his youth is a conservative one "in the sense of scepticism towards civilization which hardly implies a democracy", in this way is explained the youth's availability for the irrational currents as well as the opening to the totalitarian movements promising a renewal. Radu Gyr has been remarkable since the time of the Faculty of Letters and Philosophy, when his 
aesthetic culture is well completed and the verse chiselled, "in classicism and traditionalism, towards color, and rigor, in the possession of lyrical temperament towards a volcanic, in the register of expression, gentle in the receptivity, able to capture the geological sound, but also the smile of the eternal time"47.

Radu Gyr outlines his literary formation from its beginnings: "In my turn, a more modest creator, I debuted under the sign of symbolism, we traversed traditionalism, somehow fashionable, sometimes with a much emphasized regionalist tinge, and eventually came, to a moderate temperament as substance and structure". So, Radu Gyr wrote modernist traditionalist poetry, crossing several literary trends. Starting from the heroic ballad in which the classic blends with traditional but also with modernity and ends with carceral poetry that releases unrivalled strength and sensitivity, to Radu Gyr's poetry cannot be challenged aesthetic value, superior to the poetry of Nichifor Crainic probably nor ignoring the documentary value, being a living testimony of a regime, we hope dead and from the point of view of the prolonged pressures up to ' 90 period regarding literature. Selected as a way of survival in communist dungeons (as if they had a choice), the poetry is at Radu Gyr, a call to defend the national being as it appears in the poetry of his death condemnation Stand George, Raise Jones! ,Not for a shovel of golden bread/ Not for the bed, not for the acres, / But for your free air of tomorrow / Raise yourself up, Gheorghe, raise up Jones!", it is a country love above the being: "And as to put all your hot kiss / On the thresholds, on the doorstep, on the doors, on the icons, on everything that goes out before you, / Raise yourself up Gheorghe, raise up Jones!" The message of poetry is an ascending one in which the self-sacrifice occupies the

${ }^{47}$ Radu Gyr, The Seasons of the Shadows, [The Post by Barbu Cioculescu], Bucharest: Lucman Publishing House, 2010, p. 207. 
primordial role after the idea of national being, national consciousness, and patriotism has been raised: "Raise Gheorghe on chains, on ropes, holy horns / Up on the light of the storm, / Get up, Gheorghe, raise up John!" It is perhaps more than a proper sacrifice, sending from the last verses to the martyrdom of the "storm" imposed by communism.

There is a need for a division of carceral poetry into two categories: in the first comes poems that send to the prison experience, lived in full or sometimes transfigured into possible existence, and in the second category we could include poems whose target is imprisonment. Transformed into a devastating beast, the prison is cursed to drain, becoming "smoke and gloom" following an act of justice implied by the curse. The elements of nature are invoked: the fire, "Eat fire it, as you do not get saturate! / You always want crying/ and drink sigh wind the wind that scatters, Wind disintegratel As you do not get enough / In your great hunger, you always want blood, the hail that destroys: Hail, bend / be washed the rain, chains and cries / to smother them!" and the waters that purify every trace of injustice, "Waters make / water like them, / tears in padlocks, /The hail that destroys, Hail, bind / let the rain, the chains, and the shame, and smite them", and the waters that purify every trace of injustice, "Water make them / water like them, / tears in the padlocks, / weeping from the lattice!" so that in the end it all seems like a ghost, a nasty dream that we would not want to happen "Aiudule, Aiudule, / mad beast / make your crust, smoke and lust!" (The Curse of Aiud). Seen as a graveyard of detainees, with a number of pitch written on the lids, the prison actually reduces to the crosses of humour seen as "hungry hatches, in which condemned, hungry, dry, lying, with arms extended toward the moon ask for the white and good bread ..." (Cemetery of detainees). Also, human individuality is replaced by a number, "... tomorrow or the next day, maybe they will crump under clouds/and 532, or /807'. This number appears as a curse 
that strikes the cell, the wrinkled coat, the zodiac, etc., leading the individual becoming a number to timelessness by suspending the order and chronology: "What am I, Lord, the true one? / I am of today, from yesterday or tomorrow? I If I want to eat today from bread, /I remain in deceptions and hunger" (Smoke). The variety of inner states, sometimes encountered in the same verse, from hope to the blasphemy, makes it possible to move from being to non-existence or, more preferably, from material to spiritualized and ultimately transcendent: "Maybe I am the one who yesterday, labsorb the thorns land the sky and the honey, in turn? / Or the one who threatens tomorrow with fists, / gnashing, cursing and hoping? (...) Nowhere, I do not lose clots / I always become smoke, become smoke". Distant from the Jerusalem for which he fought, the poet feels defeated in the crusade of ideas, but he does not lose his hope: "Once, look at the great falls, / And the arms rise even more awake, / sanctified in the yarn of yesterday's wounds", being assured that no sacrifice can be in vain, and the crushed, losers become "cavaliers with cherubim faces" on whom the future can be support (Return from the crusade). The sacrifice of imprisonment is offered to the descendants who are thus obliged to fight further for these ideals. "From our fights and defeats, we lay down other stairs of destinies / a silver scale over disasters, ascend the steps of the coming world" (Ofrande). The carceral atmosphere is defined by its elements: hunger, fear, cold, and iron, and the most powerful elements of subjection to the body, soul, and human resistance are used, and hunger also has existential connotations: "How the whole universe fits into dishes, in our little cosmos between the walls, land how the time measurement no longer not beating/than the reason of eaten bread ... "(Walking in a circle), hunger for justice, hunger for heaven, hunger for the dream world, but also existential hunger "The lock was moaning from the whole creature, the guard has pulled the latch, and in my cell I remained / and the weak hunger". The suffering of hunger is so great that the 
poet has painted the universe in the colours of the food, the hallucination of hunger takes hold of it: "These pillows of cheese make me angry / the stars outside are like baked pears". I would crumble rubble debris from the nooks, "I would suck a corner of the mattress. / Open up, stove, like a cushion/ honey spreader". Suffering transforms, the verses into prayer and a curse: "Why there is not that light so that I see that on the threshold is rising / Mother of God with a great dish with sea, / with milk and unleavened bread ... / Lord, how other are feasting: piles of flesh and bread ... / Ah, my zodiac, of beast, of dog / as the saints ..., the highs!" The consciousness of this hallucinating state of hunger helps the poet to get rid of it's a slightly ironic formula: "Beregate is full of lint, my sleep is cloudy of only bread! / You jail, polenta of mother starvation!" (Hunger). The cold appears as a motif in the poetry with the same name: "The flowing, flowing, but inexhaustible fountains, / The cold, the cold, the terrible cold". Among the barrels is the day of screaming, the woods clatter from the masses. The outer universe is frozen, "The bed has grown, the cell is of paper, / the boots tremble and mumble with the pots ..." and the inner affected by hunger, hate and hankering that he no longer feels, are in the agony of the cold, "the blood slope: I'm cold, I'm cold, / Hunger, wishes, the wishes do not hurt me anymore, icicles are made under my skin / Even the wolves of my hates / they degenerated frostbite in their places. Weaken by hunger and cold, the poet feels the nearness of death, seeing in horizon / how is flying the wing of death / and we wander: tomorrow, who/ will reach the zar of destiny?" (The deads)

Carrying hardly the cross of "eternity", the poet sketches out his identity that is under the sign of death, of the cell, universe and divinity: "The world died, God died; / And only we 3 left in everything: / eternity, the cell and me / Me with the centuries back. The detachment of the world is the size of a hundred years". A hundred years ago, I had a child, a wife: "yet, 
remembering the loved beings, penetrates the bars in the form of smiles, painful smiles, shrieks that have left hurtful wounds in their hearts, or angry comedians, in a short light a woman laughs and sews, and two soft, sleepy handles like I swollen: Father" (Identity) Transformed into an animal, the poet revives in the memory his white childhood: "What white was everything, once! White bed with angels, white primary school, white Sunday, white holiday, white play with the cuckoo and ball" (Zodie), in which reading in the stars, "Write on Skye with chalk" he wanted to learn the astronomical sign without watching a glimpse of "days with claw" that lives. Protected by the "good little girl", the child walks through the "fairy-tale" land of the house, encouraged by the smile of the "uncle". Talking with them, the poet presents the grave in which "your ghost as light" is transformed into "Jivina/Animal from this turbulent dungeon" where he demands its right to death, even though "Elderly with a foggy face, with swollen steps in sadness, through death they trampled, not by life ... we did not have youth" (We did not have youth). The pain of the parents left at home, or watchers from the realm of the shadows that mourn their son is heart breaking being felt by the lyrical ego imprisoned as a desire to melt the dungeon in deep tears: "how could you shake my torment in my flesh? / how to drink your son chastisement all / gone over the black fountain salt / I would, I will empty the venom ..." (Tate's Letter). These states of deep suffering lead to prayer, the only possible comfort in such conditions: "Bloody master, Lord of light and eternity, clear, Jesus! You who have received your thorns and deep nails in your hands, / (...) / On the forefront of the land, the smile is put to you, and the now-osamanding Gentile, / teach him the bitter prayer from the moments of crossing on the cross" (Prayer). Transformed into divine splashes, tears make a bridge to heaven, attributing angelic qualities to the imprisoned, so that, after sacrificial death, they also receive those of holiness: "It will come 
soon morning / When full nation will fulminate to life, /How drowned by the saints in the graves / Priests of God with ropes tied up with tears, those who take pain will overcome their despondency, remaining steadfast in their beliefs: Put me chains and handcuffs / to sound the screaming hain / and thousands of padlocks to door, I am all that I have stayed", being aware of the fact that You are not defeated when you bleed, or even when your tears are the true defeats, the renunciation of the dream. Without abandoning the dream, the author crosses a variety of states in the relationship with the divinity; from nostalgia and melancholy to rebellion and despair, "I'm enough to get bloody / I cannot be angel anymore" (Condemnation).

Recognizing his small human weakness and weakness: "Poor, poor, poor, and rich joys", the lyrical ego is rediscovered in the crisp sacrifice that strengthens it by helping him to hope and to overcome the despondency: "Yesterday Jesus entered me into the cell, sad, what was the height of Christ. / The moon followed him into the cell / And made him taller and sadder. The poet drinks like Jesus the cup of sufferance, Where are you, Lord? I screamed at the latches / from the moon, came smoke, I felt myself in my hands, and found the traces of his nails" (As a night). The poet attributes to the pain the role of a steel staircase to the sky adorned with "topaz icons" - bones. The very century is broken into "great iron smacks" through the sacrifices that hit the stars with the wounds, we touched heaven, "but working not from lime and stone, we build / we lay with white bones", from the brick of the wounds of the wall (We have so many deaths). Prepared for the great passage, the poet asks for salvation through the "Great Gather": "I am Lord Baking for Harvest / There are only fruits and wreaths / The more I lay on my body the rust, / the more I am the soul of the garden, pray to gather it up" (I am Lord baking for picking). 
Receiving the signals of our reality, too close, but without making the usual step back ${ }^{48}$, Radu Gyr defines himself: "Do not spit on my defeats / What I worshiped I do not know to burn / raise the objects, instead of broken flag". He has the wisdom to carry his cross with dignity and to fulfill his destiny: "With the same wisdom smiles / I also wear chains and crowns, climbing to clear sunshine or descending among the storms" the grace of humor signaled in my "Calendar", but also by the divine Pronia: "And I'm going to the same shore that is not, / in the arm with friends and enemies, I I was to beat my body on the nails / or to push my lilies under the footsteps". (The wise man). Hope does not leave him in hard times, "And he tells the dead under holy sacrifices / that one morning will come / when Neamu-fulg will bleed to life, saints in the tombs" (Prayer) despite the attempted injustice. In fact, in the last word of Radu Gyr at the People's Court on Saturday, June 2, 1945, he said: "They are indeed the soul wrecks. I had a faith. And I loved it. If I said otherwise, if I deny it, you should all spit in my cheek. Regardless of whether this my belief appears today, good or bad, founded or wrong, it was, for me, true faith. I gave my soul, I worshiped my forehead. The more I suffer today when I see her bloody dead". ${ }^{4}$

This belief, best known for more than a quarter of a century, along with the "rhythm talent", brought comfort and hope to many souls imprisoned in one way or another. Infinite rondel poet, sonnets such as Columna volumes, "The Seasons of the Shadows", "Rondeluri", in which the patriotic and religious feeling is profound, Radu Gyr creates a bright poetry in which the Romanian elements are intertwined with the linguistic ones: "Even if it strikes me in the picture / a furrow and on his forehead

${ }^{48}$ Barbu Cioculescu, in Radu Gyr, The Seasons of the Shadows, Postfaţa, p. 217.

49 "Veghea", Year II, No. 4, Brasov, 2009. 
one, burns higher, younger, always, / laughing at the foam of the black thistle" (Youth without old age.) Metamorphosed in suffering, the Romanian language lay on the filth of the soul, making tears from locked and cried from the lattice (Curse of Aiud).

Radu Gyr expresses his lyrical belief: We live and suffer here in prison, our poetry must rise above any political group and be more than national. Our suffering must come to be understood and to sensitize the whole world with its purity. Deaths, suffering have created heroes, martyrs. All these cruel realities must be transfigured to be poetry, and the miracle of transfiguration comes through the mystery of the Word. It puts everything in the metaphor and breaks the normal patterns towards the spiritual universe of the infinite ${ }^{50}$. "Written most in the artistic maturity period, in the last years of the author's life, sonnets and rondels can be considered a reply to the verdict of destiny". "Who do you have a rondel / not until you have to, but pink, not a drop of blood dropped on a phrase / and a smile caught by a fungi". The broken flight does not ruin the hope of the one who hangs "but with stones in speech and recipe", and dressed with "thorns and spikes of iron", he goes on, "and here on the rainbow. We come from the era of the era, hang a bloody flight, and / or torn by a chimera ... / always this dust hopes, the wings always broke" (The Rangel of the Broken Wings). The sun, the ring sounds melancholic, considering the past and the present, "a clot of life without a clot": "What do you want, that's what it was like to be I More a thistle on the hat, of a whiplash, a more a stumbling block". The poet brings a symphony of the nature miracle, the symbolism of the floral elements being essential: "and carnations and carnations are extinguished / given to give you

${ }^{50}$ Zahu Pană, "Radu Gyr", in The Romanian Word, Year 26, No. 280 (April), p. 10. 
chrysanthemums. / I ripped them off a shore without a time, / I broke them from an unfathomable sky". Transformed into chrysanthemums, the lyrics, "They did not smile old tiers / but maybe I was snowing / my snow supreme".

The twilight of the past is golden: "Omar, Atilla, Hanibal / so good jump in the book while the sand of the hourglass turns into stone, rock and stone, and the stone slowly grows up, / day by day we enter into the rock" (The Stone Rondel on Us). Rondels, Radu Gyr's sonnets, respond to the solar flame of his temper and formed the part of the long-crafted, revived love, in which the classicist ideal of a romantic artist in substance, subjected to the rigor of form, as free as inspiring ${ }^{51}$. The author expresses his position on the work of the artist who represents him "More and more slaves to this hume, / we are ashamed to have put a long sign / on old tabs and we count the unworthy / I laughed with my forehead volumes / Poets are silent on their wooden shelves, / in complete works and poems, / and we are glad, from beyond the world / a little ironic and a little solemn" (Old File).

This is how we imagine Radu Gyr, smiling at us from beyond the world, a little ironic and a little solemn, with his grief saddened by the cruel fate of the people for whom he sacrificed.

\section{Andrei Ciurunga}

Suffering from the same injuries and resisting with the same optimism given his nature but mostly because of faith in God, Andrei Ciurunga "friend of the enemy prison/ and good bread brother without wheat" with Radu Gyr, presenting as he

${ }^{51}$ Barbu Cioculescu, in Radu Gyr, The Seasons of the Shadows, p. 218. 
states in his memoirs" "bearable from the whole odyseea of his prisons", keeping the "unbearable" for himself. The force of friendship was, on the other hand, an asset of Andrei Ciurunga's resistance, "a friend of enemy dungeon, and a good brother of bread without wheat, lyou stay beside wound near wound, and we froze in the ham, bridle beside bridle" (To Radu Gyr).

Joining the category of martyrs for poetry, Andrei Ciurunga was born on October 28, 1920, in the town of Cahul in Bessarabia. He graduated from King Carol II High School in 1939 in the city of Belgrade, retreating to Braila after the Bessarabian ceded under the Ribbentrop-Molotov Pact. He worked as editor in the newspapers "Express", "Investigation" and "Forward" and in 1949 he transferred to the editorial of the Flame magazine in Bucharest, an organ of the union of artists, writers and journalists. $\mathrm{He}$ is arrested for an anti-communist article published in the year 1945, I am present here in the newspaper "Express", being considered the "moral author" of the pro-monarchist demonstrations in Braila on 8 November. Andrei Ciurunga is closed for 29 days, during which he writes 29 poems. In 1947 he released a plaque of hostile lyrics to the Communist regime he publishes in Braila under the title "Higher Poems". That is why he is arrested in February 1950, however Andrei Ciurunga is convicted of the volume "Song of Nostalgia and War" appeared in 1944 in Chisinau, a volume that contains verses against Communism and the Soviets that destroyed the borders of the East. For four years as he was locked at the Canal, he wrote many protesters poems that other detainees learned them, by doing so, poems were saved them from forgetfulness and taken out of prison both inside and outside the country. The lyrics of survival first and then of resistance to the heavy conditions at the

${ }^{52}$ Andrei Ciurunga, Optimistic Memories, Bucharest: Publishing House of the Romanian Cultural Foundation, 1992. 
Canal, they played an essential role for both their author and those who believed in the power of the poetic word. In 1954 he was released from prison, but imprisoned in freedom. By forbidding him to write and specially to sign, Andrei Ciurunga will fight with the "animals" from freedom, getting to earn his bread as a man, a keeper, a storekeeper, etc. In 1958 he was again arrested, this time for the blame of writing the Canal poems that had begun to be broadcast both in the country and abroad, in anthologies or radio stations (in the West). Sentenced to 18 years of hard work for "crime against social order", he was released in August 1964 following the pardon decrees. The poetry written during this period kept the protest note, adding new tough valences in the address of oppressors.

In 1967 he was returned to the Writers' Union. Regarding his literary work, we must mention that between 1936-1944 he publishes four volumes of lyrics, in Bessarabia, under the signature of Robert Cahuleanu. He was forced to sign another pseudonym, after leaving the prison, editing seven poems (two for children) signing Andrei Ciurunga. Interesting is also the rebusic and satirico-humorous activity in the specialized magazines, which he carries out, from which the specific suffering humour specific to Romanian.

Confident in the destiny of the poetry and in the documentary value of it, Andrei Ciurunga turns the song into a "New Tristie at the Euxin Pontus". The history that flows - now turned, between paper will press, this terrible Danube who sheds water on three streams and the fourth blood. "And the songs that have been snatched out of slavery / you builders, with the years that come, in the books we write, a new Tristie at the Euxin Pont" (Poems of the Terrible Channel 1950-1954 Channel).

Similar to Radu Gyr, Andrei Ciurunga is troubled of the image of those from home, which tears the soul like the body torn by beatings, "we cannot rest, / we sleep on hurts and bones / In 
vain we try to sleep/ on our broken or stripped ribs". The image of the wives, the children, the brothers, designed in dream, burns the soul of the poet, harassed by the chastisement: "through sleep we open a door / to come in here / wives with ash hair / children in the cradle leave, / pop up with poisoned strollers. / Riding on horses come brothers / talking about empty stalls" (We can not rest). Thus not the proper sufferance it the great burden but the sufferance of those remained home, about whom, knowing nothing, they imagine things which constituted in reality unknown by that who was in prison. A true hymn worship to Andrei Ciurunga which he resembles to a lover, a mother, a sister, being the only reason to resist: "When in faith I felt defeated / and troubled like a fountain bottom / You always gave me a hand /which was watching my fall and caught me" (Friendship).

Sentiment persists beyond death, the poet lifting clean prayer for those who have loosened chains sooner "counting them martyrs": Receive them God how you receive the incense. "In his hot prayer the poet does not forget his loved ones together with their prayer he fraternizes to create a bridge to heaven. And to the saints in prayer: / mothers, sisters, fiancées, wives, / bearing their steps to the living dead / to find their common graves", as the entire Romanian nation kneeling in prayer does not forget: "Kneeling on harvested fields / or small clover trophies, / praying, Lord, in a voice with us / a whole nation of bloody forehead". Country love is highlighted by formulas of a rare beauty and expressiveness: "Kiss the wound of the country with clearness / and mercy them with gentle rest / those who carry the chastisement of crosses / and sleep under the knoll without crosses. Amen" (Prayer for the fallen condemned). "This serene kiss on the country wound is a gift of immortality, the sacrifice being made, for the grandchildren chrismated with peace / in 
another sail, when the wounds now / will be made seal on the country book" (Immortality).

That is why the poet refuses silence by climbing the Golgotha of suffering and drinking the glass that include "all the weeping of the country in a new oak", so that the dead which were silent to get rest in peace not shouting, "We do not keep silent, because from the wheel screaming / in our body, broken bones / and the dead crying who was silent once / with the warm mouth full of earth" (We do not keep silent). Andrei Ciurunga's lyrics are almost painful: "Someday talks about ourselves will be / as simple as about an oak", because we are aware that even this natural simplicity and perhaps not even the membership in the soul of our nation we cannot offer to our martyrs: "No one will weep in our pits, / as you do not cry lambs' grass from plains/ or the infinite blue horizones, / as we will be of all then" (Simplicity).

Being poor like Iov, without history, without the past, or even without the full geography, with the torn shirt of country, the Romanians were driven out of their own lands, though they did not taste of the forbidden tree, raising a Soviet snake, taught to suffer in silence in the expectation of a better age. It seems, however, that suffering has become a second nature and we can no longer be discarded from it, since the old heaven remains only a "dream cherub" which "in the book of life has made a pause /that has not yet been written" There is something left.) The fight for freedom is done at the price of "the ancient Dust": "Open up my ancient dust I doomed breast, from which all come / will be warmer your common pit than iris begging for a stranger". Country love get profound connotations in the love of God. "But the hungry heart after myth / is now filled, with a rare light, by the sweet hope infinite / my love for you and for country / with my time and blood I pay it honestly, Bars become lit candles on the altar of the country, which unite heaven and earth in prayer: Among the bars opened, / up to stars/ 
saint dream candles/ to inflame them (Jilava), and the cell becomes the cross of the crucifixion, Cellular cross, moment in the horn whose". The suffering written "on the thorns of the soul with the feather dip in the blood" turns into dozens of hope lyrics. If the body is tortured, laboured, and even destroyed, the soul often manages to free itself, that is why we could say that the victory of the soul could have been possible because of this feathering in the blood of the body. Thus the soul could fly and encompass its "may sky": "But I keep in myself all sky of may/immense blue hope" (Vizeta).

The reasons for the suffering are numerous, besides the imprisonment and beatings that make up the "secret" daily, at Andrei Ciurunga appears as well as to the other poets of the prison, the reason of hunger that "hurts" as a prefiguration of death. "My hunger hurts in the sucked womb / pinned in me as a peak of stitch". The reason of the cold, "cold thunder rise from the cement" (Hunger), the motive of the peep hole that appears personified in the death guard, "We are in the wall cell only two, /or three, with the round peep hole / ear listening and the eyes of ghost/ which sees, trying to hide, this enemy still failing to touch the prisoner's soul: O souls, it is well that you do not have / peep hole, like our prison!'(Peep hole). Gathering in the "heavy bag" the fruit of suffering is the purified soul by the sweat of this cross which is preparing for the great meeting: "how heavy is the bag, soul! we start, / and we hardly carrying it fully / but we are not leaving on road because tomorrow, we may / will be called, debtors, to pay". The poet brings "testimony" in front of the Creator, "The blood socked in night by ghost / (...) the nails that they have snatched away, the wounds, the slaps, the flagellations, still demanding a holy amnesty" "immense wings of forgiveness" for those who crushed him and kept him in the beasts (Testimony).

Convinced that only that way he will achieve the Resurrection, " $a$ white angel or the silence is hearing? /night is dressing in gold and mystery/ barely ringing their cruel chains / all 
prison is rising to heaven". If the prison allows the poet to touch the sky having flying instruments the hope and faith in God, incarceration in freedom it is infinitely more painful because the poet returns "nowhere": "I'm back nowhere. I do not have any more in the city / nor house, nor dreams, no brothers, / I am again free. Poor freedom, /better we would die imprisoned" (I went back to nowhere). The poet lives the guilty feeling of surviving a war which has destroyed everything, even the light in his eyes, even the "laughter of the past" but "shattered by winds and snow", "with the flag broken by bullets and storm". He does not bear the look of the lover, which gathers as "the frost of death" at the sight of the deep wounds, therefore he chooses the "abys of fate", motivating, "that in the soul it become late" (Disfiguration). On the last road and accompanied by a horse with smoke horseshoe, the poet passes the customs with the pace, remembering the rise of life, too short and too distant in time in order to remember the details: "Alele, from how long bitter weather /we started with the youth / to collect the flames and poems / from the bare blue air". Shaded by the darkness of the memories that broke a great destiny and the rust of the laurels of youth, the heart of the poet gathers "in large notebooks unfulfillments" bringing them like offering to dear beings who will collect "three splashes of blood" blooming in verses that will last for centuries (End of the Book).

\section{Conclusions}

Standing in the way of the invaders, invaded and hardpressed over time, the Romanians were able to bear efficiency all that history reserved, always living with the belief that tomorrow will be better. Though this belief was thwarted, however the love of land was stronger than the force of the invaders, and the love of the nation above the hatred and violence of strangers, or many time of those of the same nation like them. If it was easier, perhaps, to 
overcome the barbaric violence of alien invaders, it seemed more natural, with more sorrow and resignation than the physical and psychic violence of those of the same blood with them, but who became the servants of a system that wanted to be imposed, and which comprised like a big scourge a great part of mankind. Speaking of Communism, we can only say that its ideology has disturbed healthy minds that have turned into servants of utopian ideas, interpreted and distorted over time by those who embraced them, who became the executioners of their own brothers and who had never understood that man is created not only from the flesh, but is the mysterious bearer of values far above what is seen with the naked eye, means, adorned with sentiment, reason and will, and above all, with the free will which gives him the opportunity to choose between good and bad. There were, however, among the executioners of the system and many minds who at least understood these things, thing for which they were tormenting the body because this was in their hand, but they were resorting to these vices because they actually wanted to destroy these hidden values that secretly served, not the ideas of an atheist system, brutal and ruthless, but faith in a Creator full of wisdom and power, but who awaits, somewhere up, to reward each effort, remaining faithful to His promises. This faith has kept in the prisons of our country, called communists, according to the ideology of those times, a number of people who did not serve by their beliefs the atheistic ideas imposed by the regime.

How did they resist, however, to the physical torment, apparently, from human point of view, the body and the mind would not withstand? In the present paper we have tried to find the answer to this question, answer which is not easy to find when you think that by a simple "yes" or "no" or by a simple signature, these torments could end, the person facing such situation could have gone freely alongside his other counterparts. Curious is the thing that this fight was not necessarily motivated by worldly goods, but it was 
given to the intellectual level, and especially aimed at the intellectual who, at his turn, spreading light, was able to convince those around him to accept communist ideas. If at the beginning some intellectuals refused these ideas, not being necessarily Christians, but only motivated by their status as free and people with dignity, then many of them, became Christians, in prison, finding their ideas as being common with those of Christianity from which, in fact, the world, so-called secular, has borrowed most of the ideas and precepts. We are only talking about the Civil Law that borrowed and developed the divine laws of the Decalogue received by Moses on Mount Sinai. Their belief in the fact that the fight was not in vain was reinforced by the similarity between the persecution of the early Christians and them. To all this, contributed, many times, between condemned, the presence of the many ecclesiastical faces, which patiently and humiliously supported these temporal trials. This gathering of people needed, in order to cope with these attempts, to be encouraged within the prison by certain models, by leaders. It was then needed the forms to communicate ideas to others. All these have been invented in the prison world, and through their many operations they have transformed suffering into supportability, and some, moreover, have come to love the place they were temporarily imprisoned, being convinced that Someone will reward them sometime, this deprivation of this world liberty. Besides other forms of encouragement that I had just suggested, a very practiced reality, was the poetry of the prison, a strong form of resistance in all this hidden struggle, between the high walls, the usual and the passive world. Extremely valuable poets, with nostalgia and forceful lyrics, were encouraging themselves by their verse, encouraging in the same time those who were under the same conditions like them. There are realities that have been hidden for a long time, but which need to come more to light, so that those who come after us, and do not know them enough, will no longer allow, by their actions, their repetition. 
The poetry, a christian resistance support in Romanian prisons

\section{References}

1. Alexandrescu, Emil, Introduction to Romanian Literature, Bucharest: Didactic and Pedagogical Publishing House, R. A., 2007.

2. Anania, Valeriu, Memories, vol. I-II, Iași: Polirom Publishing House, 2008.

3. Bejan, Dimitrie, The joys of suffering. Evolutions from the past, vol. II, Chișinău: Cartea Moldovei Publishing House, 1996.

4. Cheese, Liviu, Catacomb Ray, Bucharest: Scara Publishing House, 2001.

5. Calciu, Gheorghe, The persecuted confessor, Piatra Neamț: Crigarux Publishing House, 2007.

6. Cistelecan, Ioana, Carceral Poetry, Bucharest: "Paralela 45" Publishing House, 2000.

7. Ciurunga, Andrei, Optimistic Memories, Bucharest: The Romanian Cultural Foundation Publishing House, 1992.

8. Codrescu, Răzvan, The Righteous near us. Confessors of the righteous faith under the communist persecution, in the Book of redressing. A Christian Perspective on Politics, Bucharest: Christiana Publishing House, 2004.

9. Crainic, Nichifor, Selected poems 1914-1944, (in the selection of the author), Bucharest: Roza Vânturilor Publishing House, 1990.

10. Crainic, Nichifor, Wanderer in my country. Memoirs in prison, Bucharest: Museum of Romanian Literature, f. a.

11. Crainic, Nichifor, Memories II, [The Calvary of Manuscripts], Bucharest: The Romanian Literature Museum "Orfeu", Dacia Publishing House, "Manuscriptum", f. a. [Edition cared and a word before by Alexandru Condeescu].

12. Crainic, Nichifor, Soprano over the abyss, Bucharest: Roza Vânturilor Publishing House, 1990.

13. Crainic, Nichifor, White days, black days, Bucharest: Roza Vânturilor Publishing House, 1991.

14. Davidescu, Ştefan Ioan, Guide through hell, preface by Flori Stănescu, Cluj-Napoca: Dacia Publishing House, 2002. 
15. Philotheus, the Monk (editor), Confession of a Christian. Father Mark, Petru Vodă Monastery.

16. Gafencu, Valeriu, "Veghea" [Calvary of Aiud], Year II, No. 4, Brașov, f. a., (2009).

17. Goma, Paul, Passions after Pitesti, Bucharest: Cartea Românească Publishing House, 1990.

18. Gyr, Radu, Poetry, Timișoara: Marineasa Publishing House, 1992.

19. Gyr, Radu, Ballades, Bucharest: Lucman Publishing House, 2006.

20. Gyr, Radu, The Seasons of the Shadows, Bucharest: Lucman Publishing House, 2010.

21. Lovinescu, Eugen, Critical, no. 2, Bucharest: Minerva Publishing House, 1982.

22. Micu, Dumitru, Thought and thinking, Bucharest: Minerva Publishing House, 1975.

23. Oprișan, Constantin, The Books of Spirit and other poems, edited by Gheorghe Calciu, Marcel Petrişor and Răzvan Codrescu, Bucharest: Christiana Publishing House, 2009.

24. Pleşu, Andrei, Picturesque and melancholy. An analysis of the sentiment in European Culture, Bucharest: Humanitas Publishing House, 1972.

25. Poets after bars, Petru Vodă Monastery, f. a., (2010).

26. Rădulescu, Mihai, History of the Romanian literature of detention. Memorialism of Reeducation, Bucharest: Ramida Publishing House, 1996.

27. Stan, Constantin, The Cross of Reeducation, (A History of "Reeducations" in Communist Dungeons in Romania 19481964), Bucharest: Christiana Publishing House, 2010.

28. Vianu, Tudor, The Art of Romanian Prosecutors, Chișinău: Hyperion Publishing House, 1991.

29. Zugravu, Cezar, Testimonies of Suffering, Iași: Moldova Publishing House, 1996. 